\title{
Cyrtobill darwini, a new species in a new orb-weaving spider genus from Australia (Araneae: Araneidae: Cyrtophorinae)
}

\author{
Volker W. Framenau ${ }^{1,2}$ and Nikolaj Scharff ${ }^{3}$ \\ ${ }^{1}$ Department of Terrestrial Zoology, Western Australian Museum, Locked Bag 49, Welshpool DC, \\ Western Australia 6986, Australia. E-mail: volker.framenau@museum.wa.gov.au \\ ${ }^{2}$ School of Animal Biology, University of Western Australia, Crawley, Western Australia 6009, Australia. \\ ${ }^{3}$ Department of Entomology, Natural History Museum of Denmark, Universitetsparken 15, \\ DK-2100 Copenhagen, Denmark \\ ${ }^{1}$ Address for correspondence
}

\begin{abstract}
A new monotypic genus of orb-weaving spider (Araneidae) with Cyrtobill darwini as type species is described from Australia. A reduced piriform spinning field of the anterior lateral spinnerets and the construction of a horizontal, dome-shaped orb-web suggest a placement of Cyrtobill in the araneid subfamily Cyrtophorinae Simon, 1895. However, the morphology of the male pedipalp is unique within the Araneidae as the cymbium has a basal, semicircular, sclerotised rim that creates a cymbial concavity. Cyrtobill darwini are small spiders of less than $5 \mathrm{~mm}$ body length and occur mainly in arid habitats such as spinifex grassland in the northern half of Australia (mainly north of $30^{\circ} \mathrm{S}$ latitude). Adult spiders have been found all year round; however, the species seems to be predominantly winter mature. We propose new generic combinations within the Australasian Cyrtophorinae: Cyrtophora crassipes (Rainbow, 1897), comb. nov.; Cyrtophora rainbowi (Roewer, 1955), comb. nov.; Cyrtophora trigona (L. Koch, 1871), comb. nov. (all originally described from Australia); and Cyrtophora gazellae (Karsch, 1878), comb. nov. (described from Papua New Guinea). In addition, we provide an updated species list for Australian Cyrtophora Simon, 1864.
\end{abstract}

\section{INTRODUCTION}

A small "new species" of orb-web spider (Araneidae) from Australia displays an intriguing thermoregulatory behaviour by adapting the resting position under their horizontal orb-web to the direction of the sun (Humphreys 1991). During the day, when temperature and net radiation are high, the spiders precisely track the solar direction and altitude and constantly adjust to the "Fabian position", i.e. with their longitudinal axis parallel to the direction of incident sunlight and with the cephalothorax facing away from the sun. The precision of the orientation of the spider to the solar azimuth and altitude far exceeds that of any other spider studied before (Humphreys 1991). Comparison of spider and ambient temperature suggested that thermoregulation was the most likely reason for the spiders' behaviour as they appeared to reduce their heat load and thus their equilibrium temperature with their environment (Humphreys 1991).

At the time of the study, the "new species" could not be identified and the author suggested that the species belonged in a new genus within the subfamily Araneinae Simon, 1895 (Humphreys 1991). However, somatic morphology, in particular the reduced piriform spinning field of the anterior lateral spinnerets (Figure 3B) and the shape and horizontal orientation of their tightly meshed web (Figure 1B) suggest a placement in the araneid subfamily Cyrtophorinae Simon, 1895. This study describes this new species in a new genus of Araneidae to celebrate the $200^{\text {th }}$ anniversary of Charles Darwin's birth in 1809 and the $150^{\text {th }}$ anniversary of the publication of his On the Origin of Species by Means of Natural Selection, arguably one of the most influential scientific books ever published. In addition, we propose a number of taxonomic changes within the Australasian Cyrtophorinae as our examination of type material of Australian Araneidae showed that some Cyrtophora are currently placed in araneine genera.

\section{METHODS}

This study is based on an exhaustive examination of Australian museum collections as well as type 

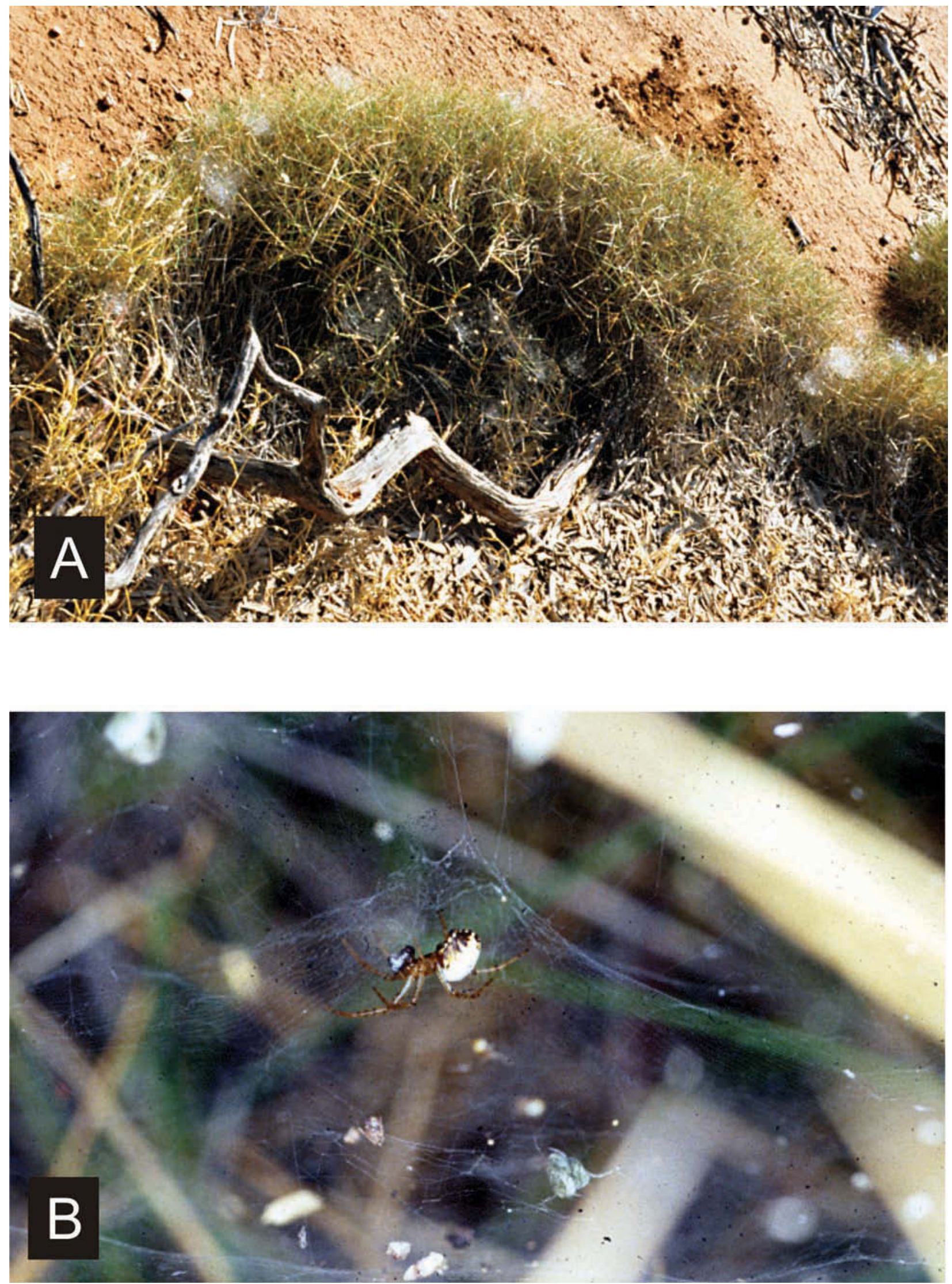

Figure 1 Cyrtobill darwini gen. nov. and sp. nov.: A, arrangement of webs in Spinifex near Learmonth, Western Australia; B, female in web. Photographs: W.F. Humphreys. 
material of relevant species deposited overseas. Descriptions are based on specimens preserved in $70 \%$ ethanol. To accurately determine the morphology and topology of male pedipalp sclerites, a pedipalp was expanded by repeated and alternate submersion in $10 \% \mathrm{KOH}$ and distilled water until maximum expansion occurred. For an examination of internal female genitalia in $70 \%$ ethanol, an epigyne was prepared by submersion in $10 \% \mathrm{KOH}$ for ca. 24 hours. The description of the views of the male pedipalp relate to their position as a limb, i.e. a full view of the bulb is a retrolateral view as in Araneidae the cymbium is situated mesally. All measurements are in millimetres $(\mathrm{mm})$.

Most images were taken with a Leica DFC500 digital camera that that was attached to a Leica MZ16A stereo microscope. Photographs were taken in different focal planes (ca. 10-20 images) and combined with the Leica Application Suite version 2.5.0R1. Photographs of expanded male pedipalps were taken with a BK+ Imaging System from Visionary Digital (http://www.visionarydigital. com) equipped with a Canon EOS 40D camera. Single images were combined with Helicon Focus (version 4.77.4) software from Helicon Soft Ltd., to increase depth of field.

A female specimen was prepared for SEM imaging by passing morphological preparations through graded ethanol series of $70 \%$ to $100 \%$, and by subsequent critical point drying in a Baltec CPC-030 Critical Point Dryer. Specimens were then coated with Platinum-Palladium in a JEOL JFC2300HR high resolution coater prior to scanning at $7 \mathrm{kV}$ in a JEOL JSM-6335F Field Emission Electron Microscope.

\section{Abbreviations}

Morphology: anterior median (AME) and anterior lateral (ALE) eyes; carapace length (CL) and width (CW); posterior median (PME) and posterior lateral (PLE) eyes; total length (TL). Spinnerets: aciniform spigot (AC), aggregate spigots (AG), anterior lateral spinneret (ALS), cylindrical spigot (CY), major ampullate spigot (MAP), minor ampullate spigot $(\mathrm{mAP})$, nubbin $(\mathrm{n})$, piriform spigots $(\mathrm{PI})$, posterior lateral spinneret (PLS), posterior median spinneret (PMS).

Collections: Australian Museum, Sydney (AM); Natural History Museum, London (England) (BMNH); Museum Victoria, Melbourne (NMV); Queensland Museum, Brisbane (QM); South Australian Museum, Adelaide (SAM); Western Australian Museum, Perth (WAM); Museum für Naturkunde, Zentralinstitut der HumboldtUniversität, Berlin (Germany) (ZMB).

\section{SYSTEMATICS}

\section{Family Araneidae Simon, 1895}

\section{Subfamily Cyrtophorinae Simon, 1895}

Cyrtophoreae Simon 1895: 770.

Cyrtophorinae Simon: Scharff and Coddington 1997: 406.

\section{Remarks}

Simon (1895) established the Cyrtophoreae to include the single genus Cyrtophora Simon, 1864 of which he considered Euetria Thorell, 1890 and Hentzia McCook, 1894 junior synonyms. Whilst Euetria remains in synonymy of Cyrtophora, Hentzia is currently recognised as valid genus under its senior synonym Mecynogea Simon, 1903 (Platnick 2009). Subsequently, many authors have placed Cyrtophora and Mecynogea in separate subfamilies (see Scharff and Coddington 1997); however Coddington (1989) suggested monophyly of Mecynogea and Cyrtophora based on spinneret morphology; in both genera the piriform spinning field on the anterior lateral spinnerets (ALS) is reduced posteriorly to a narrow ribbon (Coddington 1989: figures 15, 19; Scharff and Coddington 1997: figure 58). Furthermore, Levi and Coddington (1983) and Scharff and Coddington (1997) suggested that the web architecture (a horizontal, very tightly woven mesh with an extremely tight, permanent non-sticky spiral) of Cyrtophora and Mecynogea is diagnostic for the subfamily. The web architecture and ALS spinneret morphology described above are considered synapomorphies for the subfamily Cyrtophorinae. Levi (1997) reported similar web architectures for the genera Manogea Levi, 1997 and Kapogea Levi, 1997. The spinneret morphology of these genera is, however, unknown. The monotypic genus Megaraneus Lawrence, 1968 from Africa does not appear to be member of the Cyrtophorinae although its single species, M. gabonensis (Lucas, 1858), had previously been considered to belong to Cyrtophora (e.g. Grasshoff 1984; Platnick 2009). The web of this species is described as conventional, vertical orb-web (Lawrence 1968), an unlikely web architecture for the Cyrtophorinae.

\section{Included genera}

Cyrtobill gen. nov. (monotypic, Australia) (this study), Cyrtophora (41 species and 9 subspecies; mainly Indo-Australasian region, some species from Africa, 1 species in the New World (Framenau 2008; Platnick 2009; this study)), Kapogea (four species, Central and South America, Greater Antilles (Levi 1997)), Manogea (3 species, Central and South America (Levi 1997)) and 
Mecynogea (9 species, New World (Levi 1997)).

\section{Cyrtobill gen. nov.}

\section{Type species}

Cyrtobill darwini sp. nov.

\section{Diagnosis}

Cyrtobill males differ from other genera within the Cyrtophorinae by the presence of a unique and prominent semicircular rim at the base of the cymbium of the pedipalp which creates a basal concavity on the cymbium (Figure 4B). Females differ in the presence of a distinct spoon-shaped scape with pocket at its tip and wrinkled epigynal plate.

\section{Description}

Medium-sized (TL ca. 2.5-5 mm) orb-weaving spiders, with males of similar size as females. Carapace longer than wide, pear-shaped (Figures $2 \mathrm{~A}, \mathrm{C}, \mathrm{E})$; dorsal profile straight in lateral view; surface glabrous but with few white setae mainly in cephalic region. Fovea longitudinally V-shaped in males, a wide pit in females. Anterior median eyes largest, their row wider than that of posterior median eyes; row of posterior eyes slightly recurved; lateral eyes touching and separated by more than their diameter from posterior median eyes; posterior median eyes with narrow, canoeshaped tapetum. Sternum longer than wide (Figures 2B,D,F), with somewhat irregular, lumpy surface and with only few setae. Labium wider than long. Endites of male with large lateral tooth; Cheliceral paturon with 4 promarginal teeth, with the second apical much smaller and 3 retromarginal teeth with the apical largest. Leg formula I $>$ II $>$ IV $>$ III (males) or I $>$ IV $>$ II $>$ III (females); tibiae I and II of males similarly strong and with similar setation; coxae I of male without hook and femora II without groove. Abdomen longer than wide, extends posteriorly slightly beyond spinnerets. Booklung covers smooth.

Anterior lateral spinnerets (ALS) with more than 70 piriform spigots (PI), a major ampulate spigot (MAP) and a nubbin (n). PI spigot field commashaped, restricted posteriorly to a narrow ribbon (Figures 3A,B). PI spigot bases strongly reduced. Posterior median spinnerets (PMS) with one minor ampulate gland spigot (mAP), one nubbin (n), one cylindrical spigot (CY) and only 8 aciniform spigots (AC) (Figure 3C). Posterior lateral spinnerets (PLS) with two $\mathrm{CY}$ spigots, more than $25 \mathrm{AC}$ spigots and two aggregate spigots (AG) (Figure 3D); flagelliform spigot absent.

Male pedipalp femora with small tubercle; patellae with a single strong macroseta (Figure 4A). Paracymbium present, simple and rounded
(Figure 5C). Cymbium basally with large, almost semicircular rim that renders the cymbium somewhat triangular in mesal view and creates a basal cymbial concavity (Figure 4B). Conductor entire, cup-shaped, with well developed distal lobe and no basal lobe (Figures 4A, 5A-C). Median apophysis triangular and slightly curved, with dorso-proximal tooth (Figures 4A, 5A-C). Embolic division with radix, stipes, terminal apophysis and embolus (Figures 5BC). Radix short and thick, basal part broader than apical part, and connected to the tegulum via a membrane that is also shared with the median apophysis. Apically, the radix is connected to a well-sclerotised stipes that carries a terminal apophysis distally. Terminal apophysis consist of three parts, two heavily sclerotised with a pointy, membranous lamella in between (Figures 4A,5A,C,D). Distal haematodocha weakly developed or absent, paramedian and subterminal apophyses absent. The base of the embolus is broad and well-defined (separated from stipes by a membrane); tip of the embolus uncapped and resting on the membranous process of the terminal apophysis; embolus otherwise filiform, circular and its direction considered anti-clockwise.

Female epigyne strongly sclerotised, with slightly wrinkled basal plate and spoon-shaped scape which has a pocket at its tip (Figures 4C,E,F); spermathecae spherical with mesal vulval chamber; copulatory ducts centrally kinked (Figure 4D).

The web is a finely-meshed, horizontal and domeshaped orb with upper and longer tangle-threads and apparently without viscid silk (Figure 1B).

\section{Remarks}

The presence or absence of a subterminal apophysis in the male pedipalp is ambiguous and dependent on the interpretation of the sclerites present on the embolic division, in particular the terminal apophysis. Situated apically on the stipes is a large complex structure that somewhat wraps around the embolus. It consists of three parts: a basal, semicircular strongly sclerotised process, an apical, two-lobed also strongly sclerotised process and in between these two processes a third, membranous process that seems to accommodate the tip of the embolus (Figure 4A). Here, we interpret the whole structure as terminal apophysis, but each of the processes could also be interpreted as subterminal apophyses I and II (sensu Grasshoff 1968). It differs greatly from the terminal apophysis of Cyrtophora males which carries heavily sclerotised cuspules or ridges (Levi 1997; Framenau 2008). The base of the embolus curves clockwise following the basal, semicircular branch of the terminal apophysis, but extends far beyond this and ultimately curves anti-clockwise into the apical branch of the terminal apophysis (Figure 

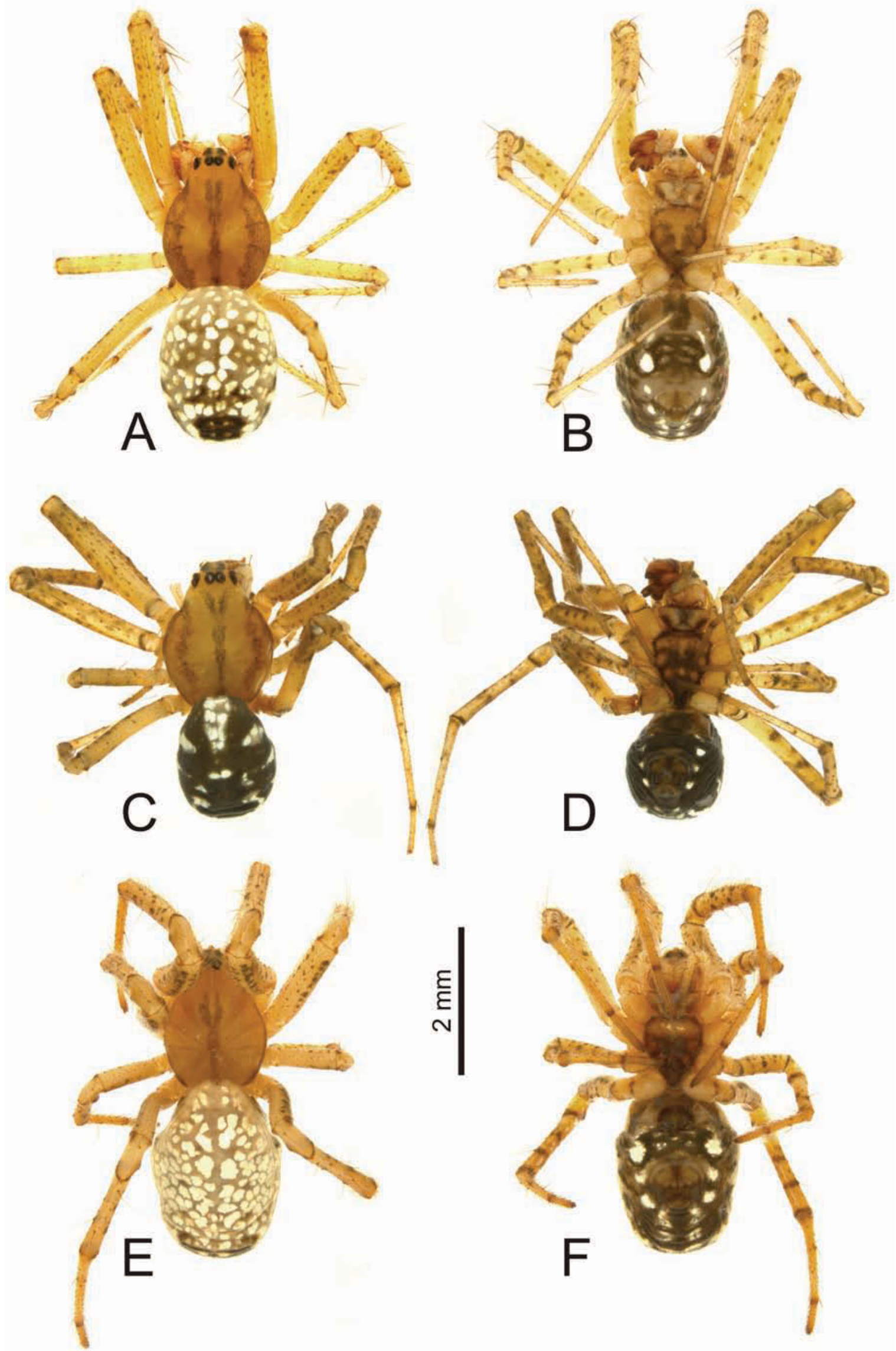

Figure 2 Cyrtobill darwini sp. nov.: A, B, male holotype (WAM T85254, from ca. 60 km E of Derby, Western Australia), dorsal and ventral view; C, D, male (QM S67603 from Drewvale, Queensland), dorsal and ventral view; E, F, female paratype (WAM T75407 from Yampire Gorge, Western Australia), dorsal and ventral view. 
$4 \mathrm{~A})$. Therefore, we consider the embolus curvature anti-clockwise as also present in Cyrtophora (e.g. Scharff and Coddington 1997). Other main pedipalp sclerites also differ greatly from those of Cyrtophora males, for example the triangular median apophysis (that is always narrow with a wide base in Cyrtophora) and the narrow conductor (that is triangular in Cyrtophora).

The posterior median spinnerets of Cyrtobill differ from those of Cyrtophora and Mecynogea, which have a well developed AC brush with more than 15 AC spigots, in the lower number of AC spigots. The flagelliform spigot of the posterior lateral spinnerets is missing in Cyrtobill, as it is in Mecynogea (Scharff and Coddington 1997).

\section{Distribution}

Cyrtobill has been found on mainland Australia, generally north of $30^{\circ} \mathrm{S}$ latitude (Figure 6).

\section{Etymology}

The generic name is a compound noun consisting of 'Cyrto-', referring to the araneid subfamily Cyrtophorinae, to which the genus is currently assigned, and '-bill' honouring Bill Humphreys from the Western Australian Museum who initially studied the thermoregulatory behaviour of the type species (Humphreys 1991). Gender masculine.

\section{Cyrtobill darwini sp. nov. \\ Figures 1-6}

\section{Material examined}

\section{Holotype}

Australia: Western Australia: $\widehat{0}, 60 \mathrm{~km}$ E of Derby, ca. $17^{\circ} 25^{\prime} \mathrm{S}, 124^{\circ} 10^{\prime} \mathrm{E}, 21$ August 1987, A.E. de Jong (WAM T85254).

\section{Paratypes}

Australia: Western Australia: 2 , Yampire Gorge, Hamersley Range National Park, $22^{\circ} 22^{\prime} \mathrm{S}$, $118^{\circ} 29^{\prime} \mathrm{E}$ ], 29 July 1987, B.Y. Main (WAM T75407, T85255).

\section{Other material examined}

Australia: New South Wales: 1 , Lake Munmorah State Recreation Reserve, Geebung, $33^{\circ} 13^{\prime} \mathrm{S}, 151^{\circ} 34^{\prime} \mathrm{E}$ (AM KS17795). Northern Territory: 1 ㅇ, Edith Falls, near Katherine, $14^{\circ} 11^{\prime} \mathrm{S}, 132^{\circ} 11^{\prime} \mathrm{E}$ (QM S69327); 1 immature + , Mt Wedge Track (Ngalia Basin), 22 $58^{\prime} 08^{\prime \prime} S, 132^{\circ} 02^{\prime} 40^{\prime \prime} \mathrm{E}$ (WAM

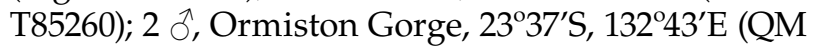
S49265). Queensland: 1 ㅇ, Blackdown Tableland, via Dingo, $23^{\circ} 50^{\prime} \mathrm{S}, 1^{\circ} 9^{\circ} 03^{\prime} \mathrm{E}$ (QM S83446); 1 +, Blackdown Tableland, via Dingo, Rainbow Creek Road, 2350'S, $149^{\circ} 03^{\prime} \mathrm{E}$ (QM S83445); 1 오 Bundaberg, $24^{\circ} 52^{\prime} \mathrm{S}, 152^{\circ} 21^{\prime} \mathrm{E}$ (QM S83450); 1
ㅇ, 2 juveniles, Cooloola, $26^{\circ} 12^{\prime} \mathrm{S}, 153^{\circ} 03^{\prime} \mathrm{E}$ (QM

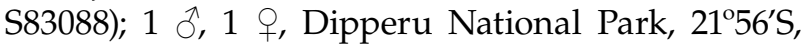
$148^{\circ} 43^{\prime} \mathrm{E}$ (QM S83447); 1 ô, Drewvale, Illaweena St,

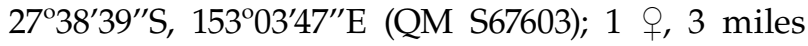
W of Duaringa, $23^{\circ} 42^{\prime \prime} \mathrm{S}, 149^{\circ} 37^{\prime \prime} \mathrm{E}$ (QM S83089); 1 +, 3 juveniles, Endfield, ca. $40 \mathrm{mi} \mathrm{W}$ of Westmar, $27^{\circ} 55^{\prime} \mathrm{S}, 149^{\circ} 43^{\prime} \mathrm{E}$ (QM S83453); 3 ㅇ, Isla Gorge, $25^{\circ} 9^{\prime} \mathrm{S}, 149^{\circ} 56^{\prime} \mathrm{E}$ (QM S83451); 1 ㅇ, Lake Broadwater, $27^{\circ} 21^{\prime} \mathrm{S}, 151^{\circ} 06^{\prime} \mathrm{E}$ (QM S83454); 1 ㅇ, Mt Isa, May Downs Station, $20^{\circ} 26^{\prime} \mathrm{S}, 139^{\circ} 04^{\prime} \mathrm{E}$ (QM S49261); 1 , Mt Moffat National Park, top shelter shed, $25^{\circ} 01^{\prime} \mathrm{S}$, 147 $57^{\circ} \mathrm{E}$ (QM S83448); 1 ㅇ, Mt Moffat, top camp, $25^{\circ} 01^{\prime} \mathrm{S}, 147^{\circ} 57^{\prime} \mathrm{E}$ (QM S83449); 1 우, Musgrave Station, $14^{\circ} 47^{\prime} \mathrm{S}, 143^{\circ} 30^{\prime} \mathrm{E}$ (QM S83452); 1 , N Northern Queensland (Gulf) and Roper Estuary, no exact locality (NMV K10341); 2 +, 1 juvenile, Teewah Creek, Cooloola, $26^{\circ} 05^{\prime} \mathrm{S}, 153^{\circ} 02^{\prime} \mathrm{E}$ (QM S83101); 2 ㅇ, Weengallon, bore end, $28^{\circ} 21^{\prime} \mathrm{S}, 148^{\circ} 58^{\prime} \mathrm{E}$ (QM S39746). South Australia: 1 , Melrose, camping grounds, $32^{\circ} 49^{\prime} \mathrm{S}, 1^{\circ} 8^{\circ} 11^{\prime} \mathrm{E}$ (SAM NN24369); 1 의 1 juvenile, Middleback Station, $32^{\circ} 57^{\prime} \mathrm{S}, 137^{\circ} 23^{\prime} \mathrm{E}$ (SAM NN24368); 1 q with eggsacs, Moonabie,

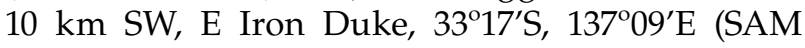
NN24370). Western Australia: 1 ऽ, Cape Range, $22^{\circ} 15^{\prime} \mathrm{S}, 1^{\circ} 4^{\circ} 43^{\prime} \mathrm{E}$ (WAM 90/644); 1 ${ }^{\dagger}, 1$ ㅇ, Cape Range, at camp near Learmonth, $22^{\circ} 15^{\prime} \mathrm{S}, 114^{\circ} 03^{\prime} \mathrm{E}$ (WAM 90/645-6); 1 ㅇ, Cape Range, near park, $21^{\circ} 55^{\prime} \mathrm{S}, 114^{\circ} 43^{\prime} \mathrm{E}$ (WAM T75398); 1 \%, Cape Range,

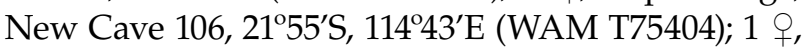
Drysdale River Station, Mt McCrann area, $15^{\circ} 51^{\prime} \mathrm{S}$, $125^{\circ} 57^{\prime} \mathrm{E}$ (WAM T75400); 1 을 Glen Herring Gorge, $21^{\circ} 10^{\prime} \mathrm{S}, 119^{\circ} 40^{\prime} \mathrm{E}$ (WAM T75408); 1 ㅇ, Learmonth, $22^{\circ} 15^{\prime} \mathrm{S}, 114^{\circ} 05^{\prime} \mathrm{E}$ (WAM T48336); 1 \%, Learmonth, $1.3 \mathrm{~km} \mathrm{~W}, 22^{\circ} 15^{\prime} \mathrm{S}, 114^{\circ} 04^{\prime} \mathrm{E}$ (WAM T75405); 1 ㅇ, Mt Florence Station, $21^{\circ} 47^{\prime} 12^{\prime \prime} \mathrm{S}, 117^{\circ} 52^{\prime} 06^{\prime \prime} \mathrm{E}$ (WAM T75415); 3 ㅇ, 4 juveniles, Nita Downs, 2 km N, $19^{\circ} 05^{\prime} \mathrm{S}, 1^{\circ} 41^{\prime} \mathrm{E}$ (WAM T75401); 7 ㅇ, 1 juvenile, North West Cape Peninsula, $22^{\circ} 15^{\prime} \mathrm{S}, 114^{\circ} 03^{\prime} \mathrm{E}$ (WAM T75399); 1 , North West Cape Peninsula, near Cave C111, 22 ${ }^{\circ} 55^{\prime} \mathrm{S}, 114^{\circ} 00^{\prime} \mathrm{E}$ (WAM T75406); 2 + , Yampire Gorge, Hamersley Range National Park, $22^{\circ} 22^{\prime}$, $118^{\circ} 29^{\prime} \mathrm{E}$ (WAM T7540203); 1 ㅇ, Yampire Gorge, Hamersley Range National Park, $22^{\circ} 22^{\prime} \mathrm{S}, 118^{\circ} 29^{\prime} \mathrm{E}$ (WAM T75402).

\section{Diagnosis}

As per genus.

\section{Description}

Male (holotype from $60 \mathrm{~km}$ E of Derby, Western Australia; WAM T85254)

Total length 3.43. Carapace (Figure 2A): 1.71 long, 1.29 wide; glabrous, yellowish-brown, grey pigmented median band that forms a fork anteriorly (Figure 2A); broad grey pigmented lateral bands; very few white setae, somewhat denser in eye region; clypeus 0.10 high. Eyes: AME 0.13, ALE 

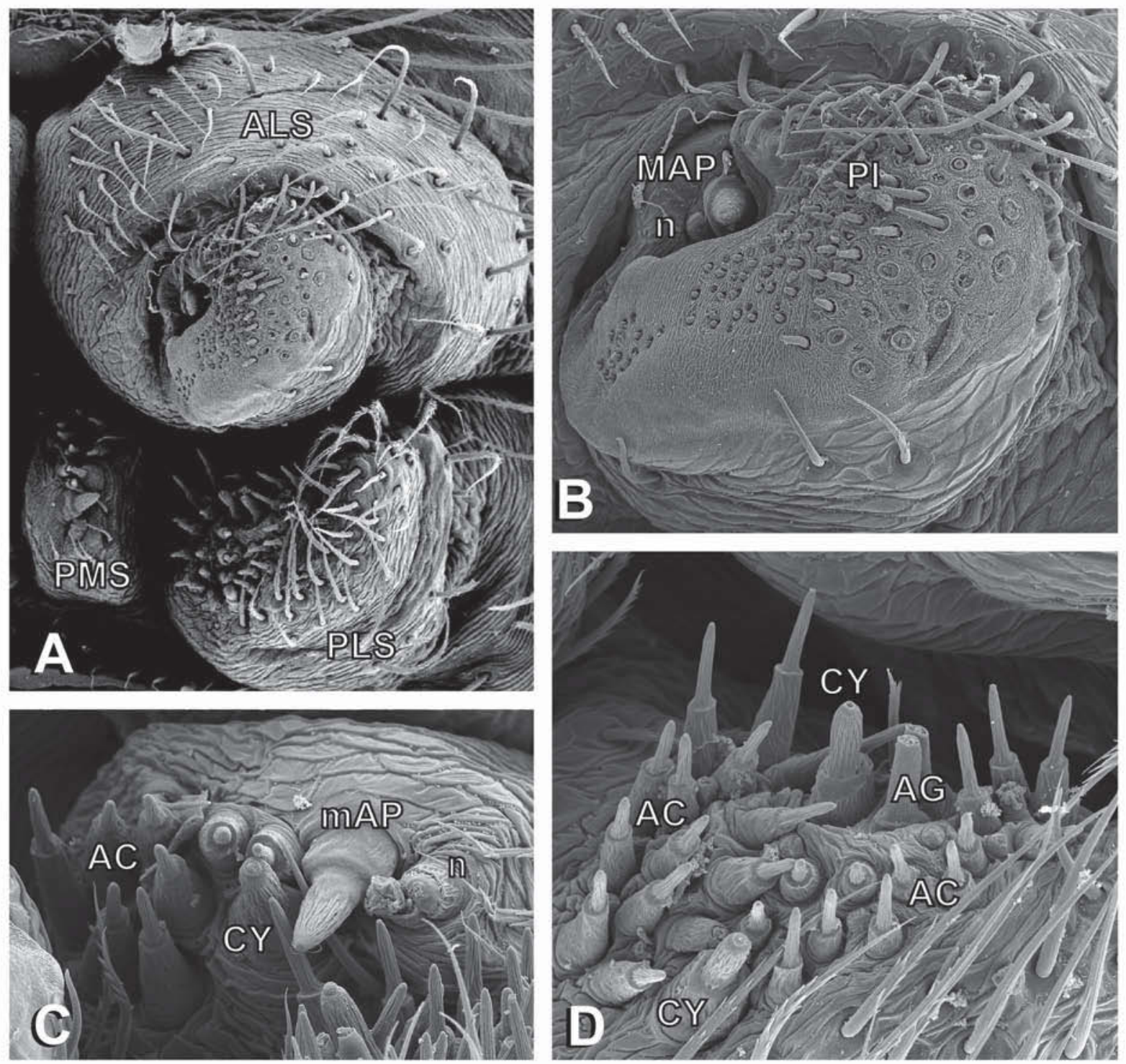

Figure 3 Cyrtobill darwini sp. nov., SEM of spinnerets, female (WAM T75400 from Drysdale River Station, Western Australia): A, spinnerets, ventral view; B, anterior lateral spinneret, ventral view; $C$, posterior median spinneret, ventral view; D, posterior lateral spinneret, ventral view. Abbreviations: AC, aciniform spigot; AG, aggregate spigots; ALS, anterior lateral spinneret; CY, cylindrical spigot; MAP, major ampullate spigot; mAP, minor ampullate spigot; n, nubbin; PI, piriform spigots; PLS, posterior lateral spinneret; PMS, posterior median spinneret.

0.07, PME 0.08, PLE 0.10; row of eyes: AME 0.33, ALE 0.52, PME 0.21, PLE 0.55. Sternum (Figure 2B): 0.81 long, 0.43 wide; yellow-brown; posterior two thirds with grey-pigmented V-shaped pattern. Labium: triangular, nearly twice as wide as long; light yellowish-brown, basally dark grey pigmented. Endites: yellowish-brown, baso-lateral with dark grey pigmented patch; Chelicerae: yellowishbrown; few brown setae medially. Pedipalps (Figures 4A,B,5A,B): as per genus description. Legs: uniformly yellowish-brown with grey spots; similar spination on all legs; lengths of segments (femur + patella + tibia + metatarsus + tarsus $=$ total length): pedipalp $0.21+0.19+0.10-+0.60=1.09$, I $1.90+0.62$ $+1.52+1.57+0.69=6.31$, II $1.76+0.57+1.33+1.43$
$+0.62=5.71$, III $1.19+0.43+0.71+0.86+0.48=3.67$, IV $1.86+0.43+1.19+1.57+0.57=5.62$. Abdomen: 1.86 long, 1.38 wide; light brown with irregular silverish-white spots and a large dark grey quadrangular spot posteriorly (Figure 2A); venter dark grey with some light brown pattern, light brown anteriorly of spinnerets; four silvery-white patches laterally of which the second is the largest (Figure 2B); anterior median spinnerets light brown, posterior lateral spinnerets laterally dark grey.

Variation. Size range: TL 2.93-4.12; CL 1.73-1.85; CW 1.27-1.42; $n=3$. The overall colouration varies and can be much darker than for the holotype described above (e.g. Figures 2C,D). 
terminal apophysis

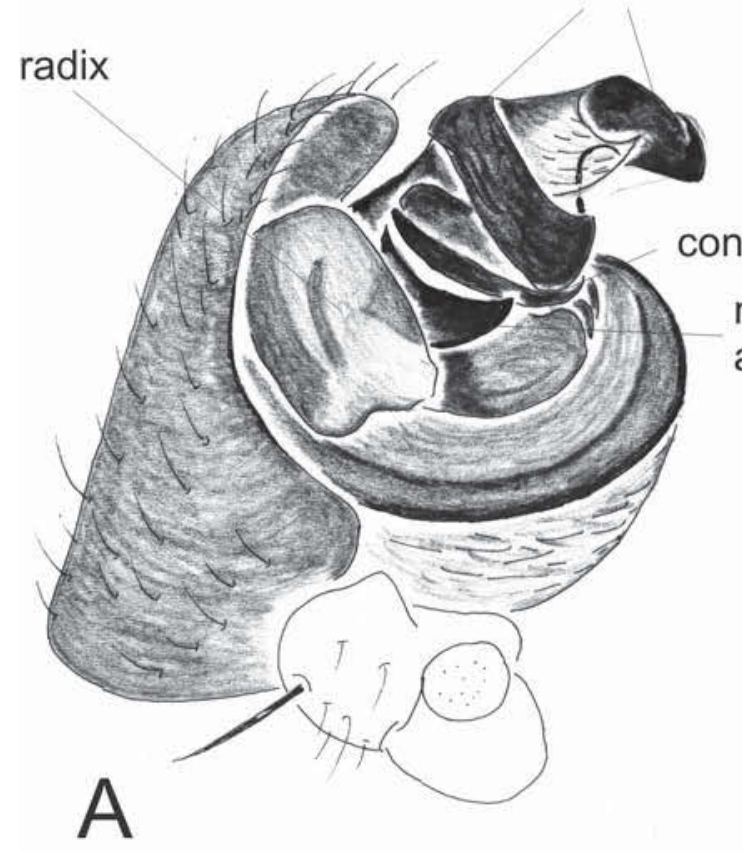

conductor median apophysis

embolus
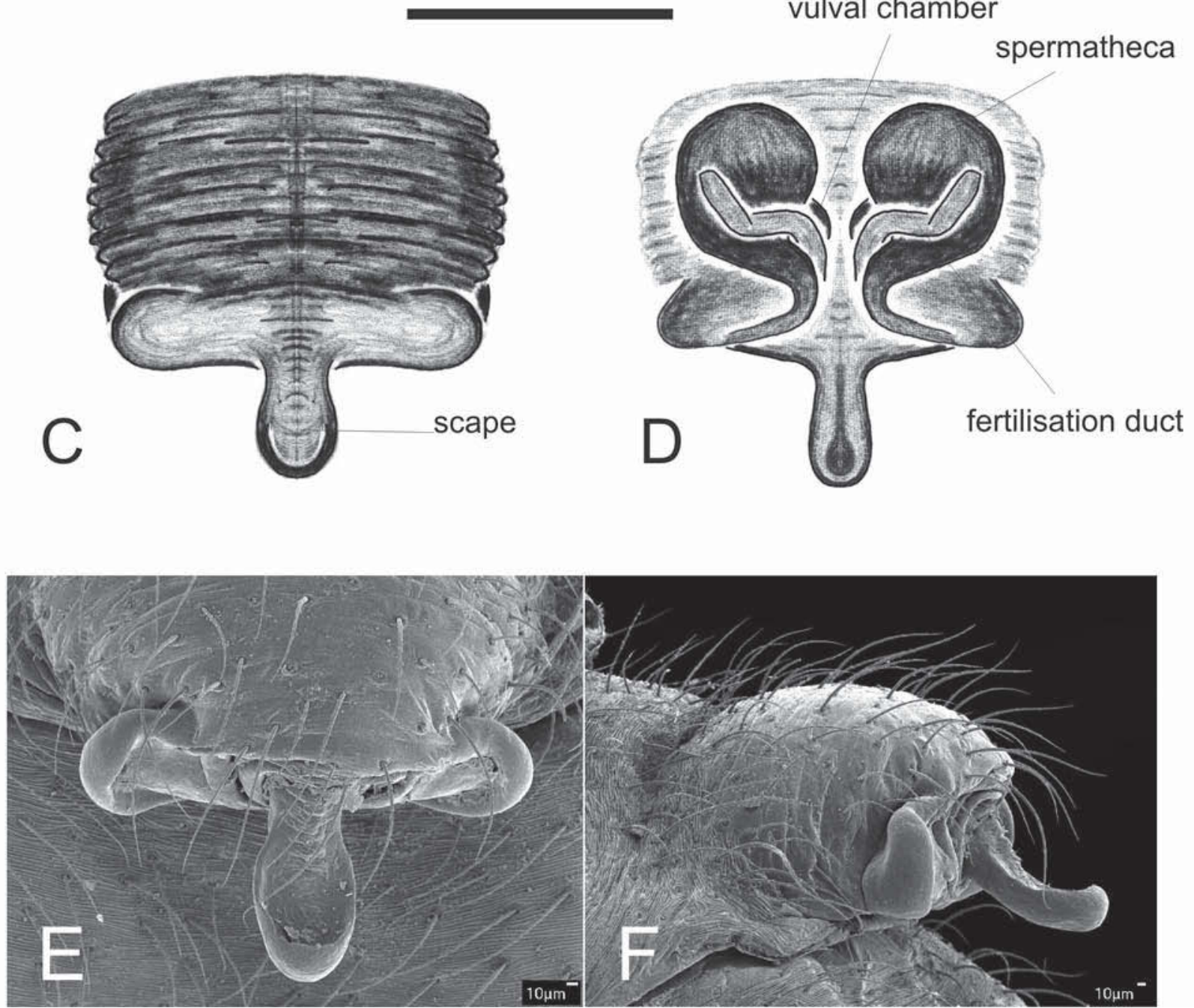

Figure 4 Cyrtobill darwini sp. nov.: Male paratype (WAM 90/645, from Learmonth, Western Australia): A, left pedipalp, ventral view; B, left pedipalp, dorsal view. Female paratype (WAM T85255, from Yampire Gorge, Western Australia): C, epigyne, ventral view; D, epigyne, dorsal view. Female paratype (WAM T75400 from Drysdale River Station, Western Australia): E, SEM of epigyne, ventral view; F, SEM of epigyne, lateral view. Scale bar: $\mathrm{A}, \mathrm{B}=0.37 \mathrm{~mm} ; \mathrm{C}, \mathrm{D}=0.31 \mathrm{~mm}$. 
Female (paratype from Yampire Gorge, Hamersley Range National Park, Western Australia; T85255)

Somatic characters of the female agree in general details with the male, except in the colouration of some body parts: carapace: lateral dark grey bands much narrower (Figure 2E). Sternum: very dark brown, only anteriorly with a light brown patch (Figure 2F). Abdomen ventrally darker, in particular in front of spinnerets (Figure 2F). Total length 4.24. Carapace: 1.81 long, 1.38 wide; clypeus 0.08 high. Eyes: AME 0.12, ALE 0.10, PME 0.11, PLE 0.09; row of eyes: AME 0.35, ALE 060.06, PME 0.25, PLE 0.50. Sternum: 1.00 long, 0.81 wide. Legs: leg formula I > IV > II > III; lengths of segments (femur + patella + tibia + metatarsus + tarsus $=$ total length): pedipalp $0.48+0.19+0.21+-+0.67=1.55$, I $1.90+0.71+1.43+1.48+0.67=6.19$, II $1.71+0.67+$ $1.29+1.38+0.64=5.69$, III $1.14+0.48+0.71+0.86+$ $0.48=3.67$, IV $1.86+0.62+1.19+1.52+0.57=5.76)$ Abdomen: 2.86 long, 1.86 wide.

Epigyne (Figures 4C-F): as per genus description.

Variation. Size range: TL 2.77-4.93; CL 1.31-2.04; CW 0.81-1.39; $n=11$.

\section{Remarks}

Despite an exhaustive examination of the Araneidae in all major Australian museum collections only a single species of Cyrtobill was recovered. The somatic morphology of $C$. darwini is somewhat similar to some species of Cyrtophora, in particular C. cicatrosa (Stoliczka, 1869) which has been found in the tropical northern parts of Australia (VWF unpublished data), but the genital morphology of Cyrtobill and Cyrtophora (e.g. Framenau 2008) are very different.

\section{Life history and habitat preferences}

Throughout Australia, adult $C$. darwini have been found all year round; however, the species seems to be winter mature in Western Australia and Northern Territory, with most records between July and September. In Queensland most adults were caught between December and February.

Cyrtobill darwini has commonly been found in dry grassland such as spinifex (Figure 1A), but also in heathland, under scribbly gum (Eucalyptus racemosa) and one record is from bluebush (Chenopodium spp.). Here the spiders build a horizontal finely-meshed, horizontal and dome-shaped orb web with upper and lower tangle-threads and apparently without sticky silk (Figure 1B; Humphreys 1991); however a variety of web names have been reported with collected specimens (e.g. 'orb-web', 'tent-web' or '3D tangle web'). The lack of sticky silk is supported by spinneret morphology, since the posterior lateral spinnerets lack a flagelliform spigot.

\section{Distribution}

As per genus.

\section{Etymology}

The specific epithet is a patronym honouring Charles Darwin (1809-1882).

\section{Cyrtophora Simon, 1864}

Euetria Thorell 1890: 109 (synonymy established in Simon 1895).

Suzumia Nakatsudi 1943: 184 (synonymy established in Yaginuma 1958).

\section{Type species}

Aranea citricola Forsskål 1775, by subsequent designation of Simon (1895).

\section{Diagnosis}

Cyrtophora differs from other araneid genera (excluding Argiope Audouin, 1826, Gea C.L. Koch, 1843, Manogea Levi, 1997, Mecynogea Simon, 1903 and Kapogea Levi, 1997) by having the second to fourth combined patella and tibia slightly shorter than the femur of the same leg and shorter than the combined metatarsus and tarsus of the same leg, by relatively heavy legs and by a slight separation of the lateral eyes (Levi 1997). Cyrtophora differs from Argiope, Gea and Mecynogea by a recurved or straight posterior eye row, from Manogea by a wider cephalic region and from Kapogea by a combination of somatic and genitalic characters, including an embolus that is placed near the median apophysis and being supported by a conductor (Levi 1997). Cytophora differs from Cyrtobill by genitalic characters, in particular the absence of a basal cymbium concavity in the male pedipalp and the absence of a scape in the female epigyne (see above).

\section{Description}

It is not possible to provide an encompassing description for Cyrtophora as part of this study as this would require an extensive review of all currently described species. Whilst there is considerable variability in somatic characters within the genus, the genitalia of male and female Cyrtophora are fairly uniform. Characteristic male pedipalp sclerites include an embolus with anticlockwise direction, a reduced median apophysis that forms a narrow or linear spur with a broad base pointing in mesal direction (i.e. away from the pedipalp bulb), a triangular conductor and a terminal apophysis that is covered with sclerotised cuspules or ridges. The female epigyne has a characteristic sinuous anterior rim without a distinct scape and the spermathecae are large and globular (e.g. Chrysanthus 1960, 1972; Levi 1997; 


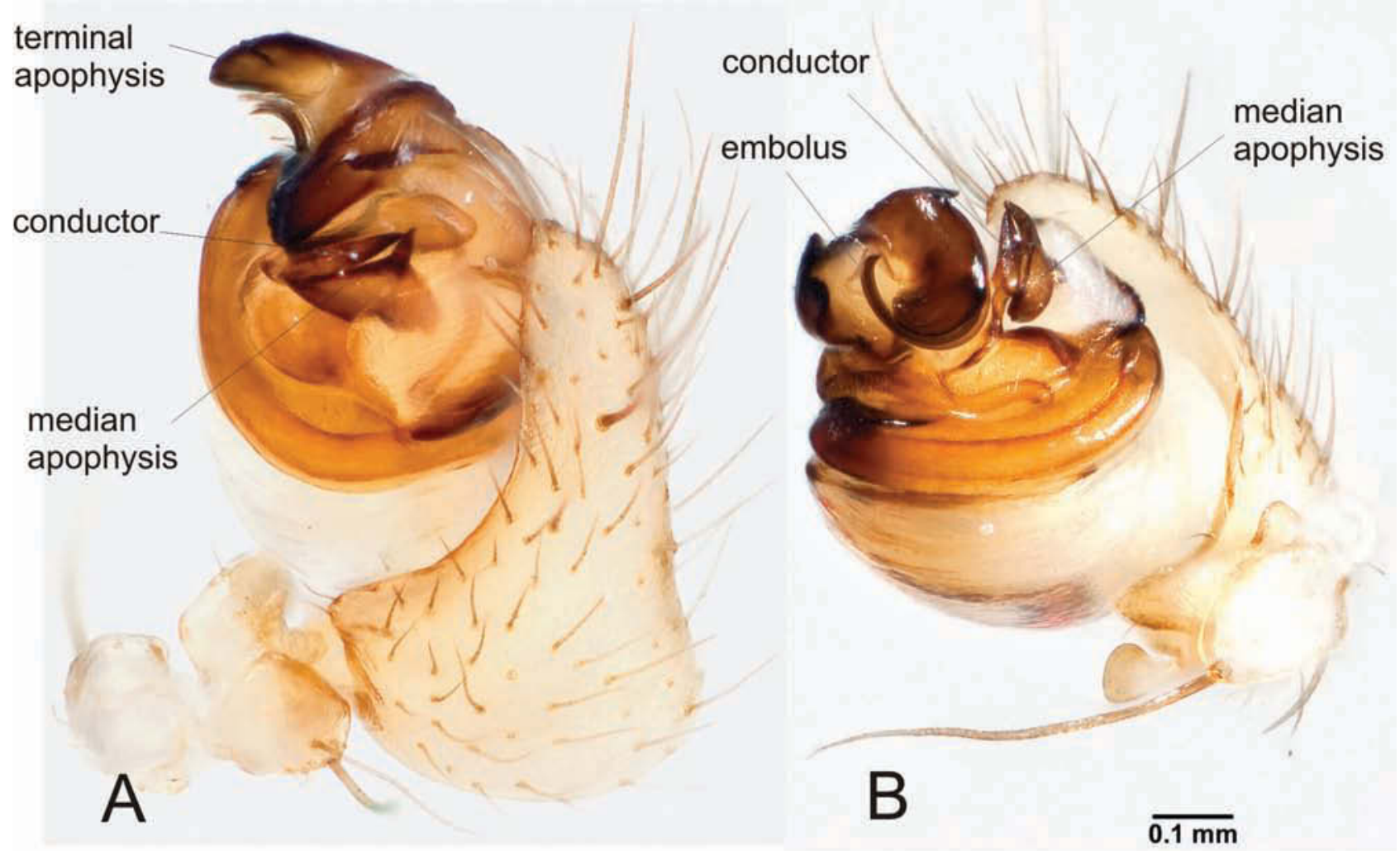

terminal apophysis

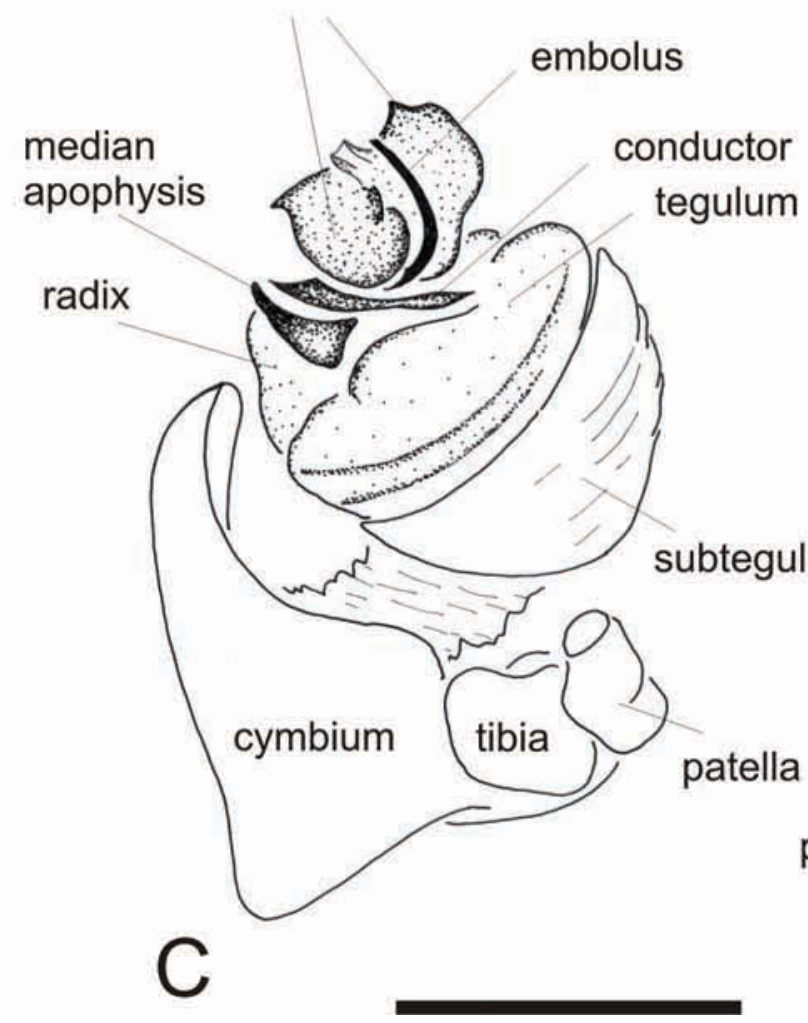

terminal apophysis

membranous process of terminal apophysis
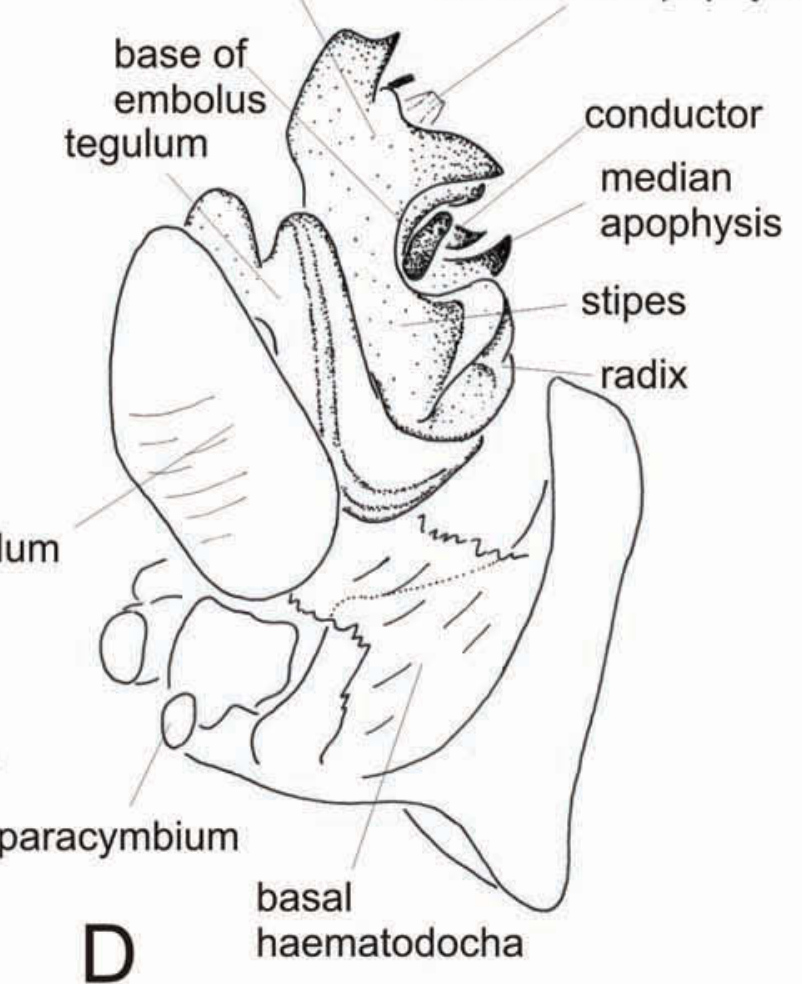

Figure 5 Cyrtobill darwini sp. nov.: A, B, male (WAM 90/644 from Cape Range, Western Australia): A, expanded right pedipalp, ventral view; B, expanded right pedipalp, mesal view. Male paratype (WAM 90/645, from Learmonth, Western Australia): C, expanded left pedipalp, ventral view; D, expanded left pedipalp, dorsal view. Scale bar: C, D - $0.45 \mathrm{~mm}$. 
Scharff and Coddington 1997; Framenau 2008). Sexual size dimorphism is pronounced in all species in which males are known, with females up to 6 times larger than males (e.g. Chrysanthus 1960, 1972; Levi 1997; Framenau 2008). Cyrtophora construct tightly woven, horizontal orb-webs with a network of supporting threads above. As the web is generally elevated centrally, it is often called "tentweb" or "dome-shaped".

\section{Cyrtophora in Australia}

Following this study, 14 valid species of Cyrtophora are reported from Australia, including one, C. unicolor (Doleschall, 1857), only known from the Indian Ocean territory of Christmas Island (Table 1). Three species are here transferred from other araneid genera following the examination of type material as part of a revision of the Australian Araneidae. A further three species originally described from elsewhere in the Oriental region are here reported for Australia for the first time. Highest diversity of Cyrtophora in Australia is in the tropical north, although one species, C. parnasia L. Koch, 1872, can be found in the temperate regions as far south as Tasmania (e.g. Hickman 1928).

Cyrtophora has not been revised since its original description although a number of Australasian species have been reviewed in a series of studies on New Guinea spiders (Chrysanthus 1959, 1960, 1971, 1972). Consequently, the species list presented here must be considered preliminary pending a comprehensive world-wide revision of Cyrtophora at the species level.

Table 1 Australian representatives of the orb-weaving spider genus Cyrtophora with comments on their distribution.

\begin{tabular}{|c|c|}
\hline Species & Comments on distribution in Australia \\
\hline $\begin{array}{l}\text { C. beccarii } \\
\text { (Thorell, 1878) }\end{array}$ & $\begin{array}{l}\text { Here firstly recorded from Australia based on a female from Wessel Island, Northern } \\
\text { Territory (SAM NN820); originally described from Amboina, Papua New Guinea. }\end{array}$ \\
\hline $\begin{array}{l}\text { C. cicatrosa } \\
\text { (Stoliczka, 1869) }\end{array}$ & $\begin{array}{l}\text { Here firstly reported for Australia based on females from Pickertaramor (SAM } \\
\text { NN25846-7) and Cahills Crossing, both Northern Territory (WAM T75409-10); } \\
\text { originally described from Kolkata, India. }\end{array}$ \\
\hline $\begin{array}{l}\text { C. citricola } \\
\text { (Forsskål, 1775) }\end{array}$ & $\begin{array}{l}\text { Presence in Australia through a synonymy with C. sculptilis L. Koch, } 1872 \text { (type locality } \\
\text { Bowen, Queensland) by Simon (1895, p. 775, footnote (1)); also some specimens identified } \\
\text { as this species in AM and QM. }\end{array}$ \\
\hline $\begin{array}{l}\text { C. cordiformis } \\
\text { (L. Koch, 1871) }\end{array}$ & $\begin{array}{l}\text { Originally described from Australia (type locality Port MacKay, Queensland); common } \\
\text { in Queensland. }\end{array}$ \\
\hline $\begin{array}{l}\text { C. crassipes } \\
\text { (Rainbow, 1897), comb. nov. }\end{array}$ & Originally described from Australia (type locality Guildford, New South Wales). \\
\hline $\begin{array}{l}\text { C. cylindroides } \\
\text { (Walckenaer, 1842) }\end{array}$ & $\begin{array}{l}\text { Presence in Australia through synonymy with Epeira nephilina L. Koch, } 1871 \text { (type } \\
\text { locality Port MacKay, Queensland) and Epeira viridipes Doleschall, } 1859 \text { (reported from } \\
\text { Peak Downs, Queensland by Keyserling (1887)) by Simon (1895, p. 775, footnote (2)); } \\
\text { specimens from Queensland identified as this species in QM and AM. }\end{array}$ \\
\hline $\begin{array}{l}\text { C. exanthematica } \\
\text { (Doleschall, 1859) }\end{array}$ & $\begin{array}{l}\text { Listed in Australia by Keyserling (1887) from Rockhampton and Cape York, both } \\
\text { Queensland; common in Queensland; few specimens from New South Wales in AM. }\end{array}$ \\
\hline $\begin{array}{l}\text { C. hirta } \\
\text { L. Koch, } 1872\end{array}$ & $\begin{array}{l}\text { Originally described from Australia (type locality Bowen, Queensland); common in } \\
\text { Queensland; few specimens from New South Wales in AM. }\end{array}$ \\
\hline $\begin{array}{l}\text { C. moluccensis } \\
\text { (Doleschall, 1857) }\end{array}$ & Reported for Australia, for example, in Chrysanthus (1959); common in Queensland. \\
\hline $\begin{array}{l}\text { C. monulfi } \\
\text { Chrysanthus, } 1960\end{array}$ & $\begin{array}{l}\text { Here firstly recorded from Australia based on a female from Darwin, Northern } \\
\text { Territory (QM S12067); originally described from Merauke, Papua New Guinea. }\end{array}$ \\
\hline $\begin{array}{l}\text { C. parnasia } \\
\text { L. Koch, } 1872\end{array}$ & $\begin{array}{l}\text { Originally described from Australia (type locality Bowen, Queensland); only species } \\
\text { common in temperate regions, e.g. into Tasmania (Hickman 1928) and in southern } \\
\text { Western Australia (VWF pers. obs.). }\end{array}$ \\
\hline $\begin{array}{l}\text { C. rainbowi } \\
\text { (Roewer, 1955), comb. nov. }\end{array}$ & $\begin{array}{l}\text { Originally described as Epeira pallida Rainbow, } 1897 \text { from Australia (type locality } \\
\text { Guildford, New South Wales). }\end{array}$ \\
\hline $\begin{array}{l}\text { C. trigona } \\
\text { (L. Koch, 1871), comb. nov. }\end{array}$ & $\begin{array}{l}\text { Originally described as Epeira trigona L. Koch, } 1871 \text { from Australia (type locality Port } \\
\text { Mackay, Queensland). }\end{array}$ \\
\hline $\begin{array}{l}\text { C. unicolor } \\
\text { (Doleschall, 1857) }\end{array}$ & $\begin{array}{l}\text { Christmas Island (Australian Indian Ocean territory), currently not known from } \\
\text { mainland Australia (Framenau 2008). }\end{array}$ \\
\hline
\end{tabular}




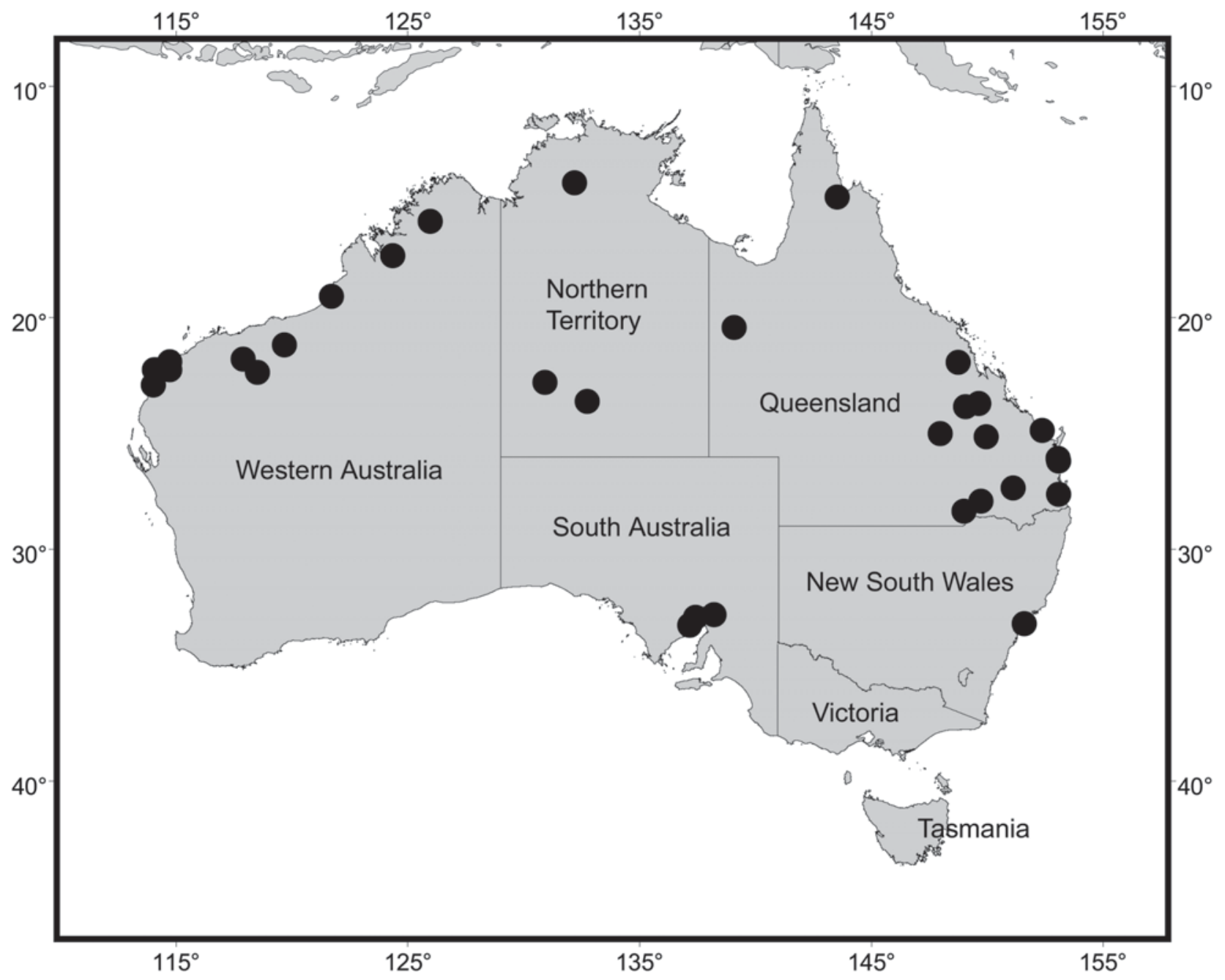

Figure 6 Cyrtobill darwini sp. nov.: distribution records in Australia.

Cyrtophora crassipes (Rainbow, 1897), comb. nov.

Epeira crassipes Rainbow, 1897: 515-517, plate 17, figures 2, 2a.

Araneus crassipes (Rainbow): Rainbow 1911: 184; Bonnet 1955: 471.

Aranea crassipes (Rainbow): Roewer 1942: 826.

\section{Material examined}

\section{Syntypes}

Australia: New South Wales: 3 , 1 juvenile,

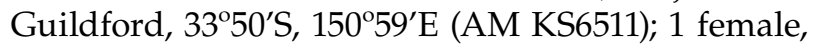
6 juveniles, same data (AM KS6512).

\section{Remarks}

Somatic and genital morphology of the four female syntypes of Epeira crassipes undoubtedly identify this species as belonging to Cyrtophora. In addition, the description of the web of this species by Rainbow (1897, p. 534) reflects the typical shape of a Cyrtophora snare: "The orb-like mesh of this spider is always suspended horizontally, and the radii and concentric rings are exceedingly fine and closely woven". Therefore, we transfer this species to Cyrtophora, C. crassipes (Rainbow, 1897), comb. nov.

\section{Cyrtophora rainbowi (Roewer, 1955), comb. nov.}

Epeira pallida Rainbow, 1897: 514-515, plate 17, figure 1.

Cyclosa pallida (Rainbow): Rainbow, 1909: 219; Rainbow 1911: 180.

Cyclosa rainbowi Roewer, 1955: 758 (replacement name for Epeira pallida Rainbow, 1897, preoccupied by Epeira pallida Walckenaer, 1805).

\section{Material examined}

Syntypes

Australia: New South Wales: 2 , Guildford, 3350'S, 15059'E (AM KS6527). 


\section{Remarks}

Somatic and genitalic morphology of the two female syntypes unequivocally conform to the diagnosis and description of Cyrtophora as above and therefore we propose the transfer of this species this genus, C. rainbowi (Roewer, 1955), comb. nov. Rainbow (1897) described this species in the same publication and from the same locality as $C$. crassipes and also confirms similar web architecture for both species (Rainbow 1897; p. 535: “E. pallida (...) fabricates a snare and nest like the one just described" [= C. crassipes $]$ ). It is therefore surprising that Rainbow (1909) subsequently transferred this species to Cyclosa Menge, 1866 although he reiterated in the same publication the unusual web architecture of Australian Cyrtophora.

\section{Cyrtophora trigona (L. Koch, 1871), comb. nov.}

Epeira trigona L. Koch, 1871: 50-51, plate 4, figures 1, 1a-b; Bradley 1876: 144; Karsch 1878: 789; Thorell 1881: 687.

Araneus trigonus (L. Koch): Rainbow 1898: 340; Rainbow 1899: 112; Rainbow 1916: 99; Bonnet 1955: 616; Rack 1961: 25.

Araneus trigona (L. Koch): Rainbow 1911: 195.

Aranea trigona (L. Koch): Roewer 1942: 834.

\section{Material examined}

\section{Syntypes}

Australia: Queensland: 1 , Port Mackay, $21^{\circ} 10^{\prime}$ S, 149 ${ }^{\circ} 14^{\prime} \mathrm{E}$ (BMNH 1915.3.5.1242); 1 ㅇ, same locality, Museum Godeffroy 7474 (ZMH Rack (1961)-catalog no. 283).

\section{Remarks}

Somatic and genitalic morphology of the female syntypes of Epeira trigona clearly conform to the genus Cyrtophora. Consequently, we here transfer the species to Cyrtophora, C. trigona (L. Koch, 1871), comb. nov. Somatic morphology of $C$. trigona is similar to that of C. unicolor (Doleschall, 1857), however it lacks the strong tubercles on the carapace of females (e.g., Framenau 2008).

Rack (1961) listed the female lodged in ZMH as holotype; however it remains unclear from $\mathrm{L}$. Koch's (1871) original description if the species is based on a single holotype or multiple specimens. As both specimens listed above are equally likely types we consider them here as syntypes.

\section{Cyrtophora gazellae (Karsch, 1878), comb nov.}

Epeira gazellae Karsch, 1878: 803-804; Thorell 1881: 687.

Aranea gazellae (Karsch): Roewer 1942: 828.
Araneus gazellae (Karsch): Bonnet 1955: 506.

\section{Material examined}

Holotype

Papua New Guinea: New Britain: 1 , Gazelle Peninsula, ca. $4^{\circ} 20^{\prime} \mathrm{S}, 152^{\circ} 00^{\prime} \mathrm{E}$, Gazelle Expedition (ZMB 2587).

\section{Remarks}

The holotype female of Epeira gazellae unequivocally belongs to the genus Cyrtophora, based on somatic and genitalic characters as described for the genus above. Therefore we here propose the new placement in Cyrtophora, C. gazellae (Karsch, 1878) comb. nov.

Cyrtophora gazellae was originally described from Papua New Guinea and is currently not considered part of the Australian fauna. However, as a number of originally Papuan species were subsequently found in tropical northern Australia, the taxonomic change of this species is included here to facilitate incorporating it in a future review of Australian Cyrtophora and a revision of Cyrtophora as a whole.

\section{ACKNOWLEDGEMENTS}

We are grateful to all curators and collection managers in many Australian museums and institutions overseas for their constant support during our systematic studies of Australian orbweaving spiders. For this study, special mention goes to (in no particular order): Robert Raven, Owen Seeman and Barbara Baehr (QM), David Hirst (SAM), Graham Milledge and Helen Smith $(\mathrm{AM})$, Janet Beccaloni (BMNH), Peter Lillywhite (NMV) and Jason Dunlop (ZMB). Bill Humphreys provided the photographs for Figure 1. Jonathan Coddington made his BK+ Imaging System at the Smithsonian Institution, Washington DC, USA, available for this study and helped with the photographs of the male Cyrtobill pedipalps (Figures 5A,B). We thank Mark Harvey and Paul Doughty for inviting us to contribute to this issue in honour of Charles Darwin. Gustavo Hormiga provided helpful comments as reviewer of this study. This study was supported by the Australian Biological Resources Study (ABRS; grant 205-24) and a Danish Natural Science Research Council Award 21020502 (to NS).

\section{REFERENCES}

Bonnet, P. (1955). Bibliographia Araneorum. Analyse Méthodique de Toute la Littérature Aranéologique Jusqu'en 1939. Tome II. Douladoure: Toulouse.

Bradley, H.H.B. (1876). The Araneids of the "Chevert" Expedition. Proceedings of the Linnean Society of New South Wales 1: 137-151. 
Chrysanthus, F. (1959). Spiders from South New Guinea II. Nova Guinea, N.S. 10: 197-206.

Chrysanthus, F. (1960). Spiders from South New Guinea III. Nova Guinea 3: 23-42.

Chrysanthus, F. (1971). Further notes on the spiders of New Guinea I (Argyopidae). Zoologische Verhandelingen 113: 1-52.

Chrysanthus, F. (1972). Description of the hitherto unknown males of Argiope reinwardti (Doleschall, 1859) and Cyrtophora monulfi Chrysanthus, 1960 (Araneae, Argiopidae). Zoologische Mededelingen 47: 156-159.

Coddington, J.A. (1989). Spinneret silk spigot morphology: evidence for the monophyly of orbweaving spiders, Cyrtophorinae (Araneidae), and the group Theridiidae plus Nesticidae. Journal of Arachnology 17: 71-95.

Framenau, V.W. (2008). The male of the orb-weaving spider Cyrtophora unicolor (Araneae, Araneidae). Journal of Arachnology 36: 131-135.

Grasshoff, M. (1968). Morphologische Kriterien als Ausdruck von Artgrenzen bei Radnetzspinnen der Subfamilie Araneinae (Arachnida: Araneae: Araneidae). Abhandlungen der Senckenbergischen Naturforschenden Gesellschaft 516: 1-100.

Grasshoff, M. (1984). Die Radnetzspinnen-Gattung Caerostris (Arachnida: Araneae). Revue Zoologique Africaine 98: 725-765.

Hickman, V.V. (1928). Studies in Tasmanian spiders. Part II. Papers and Proceedings of the Royal Society of Tasmania 1927: 158-175.

Humphreys, W.F. (1991). Thermal behaviour of a small spider (Araneae: Araneidae: Araneinae) on horizontal webs in semi-arid Western Australia. Behavioral Ecology and Sociobiology 28: 47-54.

Karsch, F. (1878). Exotisch-araneologisches II. Zeitschrift für die gesamten Naturwissenschaften 51: 771-826.

Koch, L. (1871). Die Arachniden Australiens nach der Natur beschrieben und abgebildet. 1. Theil. 1. Lieferung. Verlag von Bauer und Raspe: Nürnberg.

Lawrence, R.F. (1968). Four new spiders from southern Africa (Araneae). Annals of the Natal Museum 20: 109-121.

Levi, H.W. (1980). The orb-weaver genus Mecynogea, the subfamily Metinae and the genera Pachygnatha, Glenognatha and Azilia of the subfamily Tetragnathinae north of Mexico (Araneae: Araneidae). Bulletin of the Museum of Comparative Zoology 149: 1-74.

Levi, H.W. (1997). The American orb weavers of the genera Mecynogea, Manogea, Kapogea and Cyrtophora (Araneae: Araneidae). Bulletin of the Museum of Comparative Zoology 155: 215-255.

Levi, H.W. and Coddington, J.A. (1983). Progress report on the phylogeny of the orb-weaving family Araneidae and the superfamily Araneoidea
(Arachnida: Araneae) (Abstract). Verhandlungen des naturwissenschaftlen Vereins in Hamburg (NF) 26: 151-154.

Platnick, N.I. (2009). The World Spider Catalog, Version 10.0 http:/ / research.amnh.org/entomology/spiders / catalog/INTRO1.html. American Museum of Natural History (accessed 19 August 2009).

Rack, G. (1961). Die Entomologischen Sammlungen des Zoologischen Staatsinstituts und Zoologischen Museums Hamburg. II. Teil. Chelicerata II: Araneae. Mitteilungen des Hamburgischen Zoologischen Museums und Instituts 59: 1-60.

Rainbow, W.J. (1897). Descriptions of some new Araneidae of New South Wales. No. 8. Proceedings of the Linnean Society of New South Wales 22: 514-553.

Rainbow, W.J. (1898). Contribution to a knowledge of the arachnidan fauna of British New Guinea. Proceedings of the Linnean Society of New South Wales 23: 328-356.

Rainbow, W.J. (1899). Contribution to a knowledge of Papuan Arachnida. Records of the Australian Museum 3: 108-118.

Rainbow, W.J. (1909). Notes on the architecture, nesting habits, and life histories of Australian Araneae, based on specimens in the Australian Museum. Records of the Australian Museum 7: 212-234.

Rainbow, W.J. (1911). A census of Australian Araneidae. Records of the Australian Museum 9: 107-319.

Rainbow, W.J. (1916). Arachnida from northern Queensland. Records of the Australian Museum 11: 31-64, 79-119.

Roewer, C. F. (1942). Katalog der Araneae von 1758 bis 1940. 1. Band (Mesothelae, Orthognatha, Labidognatha: Dysderaeformia, Scytodiformia, Pholciformia, Zodariiformia, Hersiliaeformia, Argyopiformia). Paul Budy: Bremen.

Roewer, C.F. (1955). Katalog der Araneae von 1758 bis 1940, bzw. 1954. 2. Band, Abteilung A (Lycosaeformia, Dionycha [excl. Salticiformia]). Institut Royal des Sciences Naturelles de Belgique : Bruxelles.

Scharff, N. and Coddington, J.A. (1997). A phylogenetic analysis of the orb-weaving spider family Araneidae (Arachnida, Araneae). Zoological Journal of the Linnean Society 120: 355-434.

Simon, E. (1895). Histoire naturelle des araignées. Volume 1. Roret: Paris.

Thorell, T. (1881). Studi sui ragni Malesi e Papuani. III. Ragni dell'Austro-Malesia e del Capo York, conservati ne Museo Civico di Storia Naturale die Genova. Annali del Museo Civico di Storia Naturale di Genova 17: $1-727$.

Yaginuma. T. (1958). Revision of Japanese spiders of family Argiopidae. II. Genus Cyrtophora. Acta Arachnologica 16:10-17.

Manuscript received 14 April 2009; accepted 27 August 2009. 